\title{
Sustainability of Microfinance Institutions in Financial Crisis ${ }^{\#}$
}

\author{
Lenka DOKULILOVÁ ${ }^{*}$ Karel JANDA ${ }^{* *}$ \\ Pavel ZETEK ${ }^{* * *}$
}

\section{Introduction}

In recent years, microfinance has received increasing attention in many discussions about the never ending problems of poverty and economic growth promotion. The role of microfinance institutions (MFI) was expected to have increased importance after the financial crisis in the USA. Microfinance has demonstrated that poor people are viable customers as long as their financing is approached in the right way, which required that moral hazard, adverse selection and other agency problems were mitigated. Microfinance development led to a number of strong institutions focusing on poor people's finance and it begun to attract the interest of private investors. But despite these achievements, there is still a long way to go to extend the access to those microfinance institutions to all who need financial services.

This paper focuses on sustainability of microfinance institutions during financial crisis. Following this point of view, we first describe the position of MFI, products and services in modern microfinance and their

\# The work on this paper was supported by the Czech Science Foundation, grants 402/09/0380 and 403/10/1235 and by the research project MSM0021620841.

* Mgr. Lenka Dokulilová - student; Institute of Economic Studies, Faculty of Social Sciences, Charles University, Opletalova 26, 11000 Prague 1, Czech Republic; <lenka.dokulilova@centrum.cz>.

** Prof. Ing. Karel Janda M. A., Dr., Ph.D. - Professor; Department of Banking and Insurance, Faculty of Finance and Accounting, University of Economics Prague, W. Churchill sq. 4, 13067 Prague 3, Czech Republic - Professor; Institute of Economic Studies, Faculty of Social Sciences, Charles University, Prague, Opletalova 26, 11000 Prague 1, Czech Republic - Affiliate Fellow; CERGE-EI, Prague, Politických vězňu, 11121 Praha 1, Czech Republic; <Karel-Janda@ seznam.cz>.

${ }^{* * * *}$ Ing. Zetek Pavel - Ph.D. student; Department of Banking and Insurance, Faculty of Finance and Accounting, University of Economics Prague, W. Churchill sq. 4, 13067 Prague 3, Czech Republic; <zetekpavel@centrum.cz>. 
Dokulilová L. - Janda, K. - Zetek, P.: Sustainability of Microfinance Institutions in Financial Crisis.

position in developing countries. Next, we concentrate on the role and the performance of MFIs worldwide in the light of financial and economic crisis in recent years.

\section{Microfinance institutions as providers of financial services}

Microfinance institutions originated in developing economies. It might be found that microfinance is important especially in the lending to rural population. Microfinance institutions complement and sometimes substitute other ways of providing credit to rural population like government credit guarantees and subsidies (Čechura, 2006, 2008, 2009). For the understanding of their functions and operations, their position in the finance services sector in the developing countries has to be explained first.

The most obvious group of finance providers both in developed and developing countries is represented by the well-known traditional banks. These institutions never (or hardly ever) provide financial services to the poor clients. And there are many logical reasons for that. The problem of adverse selection and information asymmetry (ex ante as well as ex post moral hazard) is substantially more severe in the case of these customers. The poor has no or very little income, they do not have steady employment and cannot offer any collateral, which banks require. The poor clients have no credit history, banks are too far away to verify and observe their behavior - there is little information. In addition, the loans are generally far too small compared to transaction costs (bad information, no addresses, no infrastructure...). Despite these facts, the potential of credit markets in developing countries is high. Potential entrepreneurs are usually missing starting seed capital, but returns on certain small businesses are fairly high. The returns on businesses in agriculture and trade can be above $100 \%$ annually (Mexico, Ghana, Kenya). According to the empirical evidence, annual returns on investments in microenterprises often exceed $100 \%$ too.

The other source of finance is represented by microfinance institutions, which could be classified into three main categories, depending on the regulatory thresholds of their organizational structures: 
Informal institutions (self-help groups, credit associations, families, individual money lenders) properly do not have the status of institutions. They are providers of microfinance services on a voluntary basis and are not subject to any kind of control or regulation.

Semi-formal institutions are usually registered entities, subject to all relevant general laws. They can be defined as microfinance financial intermediaries (MFFIs) and they represent the most traditional category of MFI: they are mostly credit-only institutions which provide various financial services but generally they do not collect deposits or alternatively they cannot grant credit, as is the case with postal saving banks. Therefore, MFFIs are subject to financial regulatory requirements, according to the wideness of their financial intermediation activities, but they are not under banking regulation. Within this category, it is possible to include different types of institutions with different structural and organizational complexity (financial NGOs, financial cooperatives, credit unions, postal saving banks). The most popular and widespread are, however, financial NGOs that operate principally by offering microcredit as part of development projects, often combined with the offer of technical assistance and other social interventions for beneficiaries. To this aim the NGOs make use, in part or entirely, of funds donated by supranational institutions and agencies, as well as from donor states. Some of the most developed NGOs offer different types of financial services, raise private funds and collect savings from their clients.

Formal institutions can be further classified into three main categories: microfinance banks (MFBs), microfinance oriented banks (MFOBs) and microfinance sensitive banks (MFSBs). They can all offer credit and they are all deposit-taking institutions: for these reasons, they are all under banking regulation. Within MFBs, it is possible to list a limited number of pure microfinance banks (PMFBs), cooperative banks and development banks.

PMFBs are banks specialized in offering only microfinance services. These may be the result of upscaling of NGOs specialized in microcredit that have converted to banks in order to maximize the economic sustainability of their initiatives and widen their client base. Alternatively, such intermediaries may result from a process of privatization of public banks, with the aim of providing financial support to the local community. Lastly, they may be newly created banks which aim to enter into the microfinance market because they have been attracted by the 
Dokulilová L. - Janda, K. - Zetek, P.: Sustainability of Microfinance Institutions in Financial Crisis.

large profits and positive performances achieved by intermediaries specialized in micro-enterprises.

Microfinance services can also be offered by different types of cooperative institutions, which operate exclusively or mainly for the benefit of their own members. These include more organized credit unions - such as those based in the UK and Ireland- which offer credit and other services to their own members; the Rotating Savings and Credit Associations (ROSCAs), more common in developing countries, which provide rotating credit to their own members using resources from a centralized fund made available by the savings of the members themselves; and cooperative credit banks. Despite their differences, the common characteristics of these institutions lie in the legal status of cooperative companies and in the possibility to collect time deposits, mainly through partners. On the other hand, the chance to offer demand deposits is largely prohibited by regulatory authorities, due to the higher complexity that would derive for those institutions in liquidity management, as well as for the higher contribution to the systematic risk. Development banks are large, centralized, and usually government-owned banks created to support specific sectors (small business developing banks) or geographic areas (rural development banks); in some developing countries they also take the form of private banks. Finally, in recent years, within formal microfinance institutions, it has been possible to include some commercial banks, banking groups and financial conglomerates. Here, two categories of intermediaries can be identified: microfinance-oriented banks and microfinance-sensitive banks.

In the area of microfinance-oriented banks it is possible to group together all the banks or financial institutions which are specialized in financing small to medium enterprises and micro-enterprises and which are therefore professionally inclined to take an active part in microfinance programs. These are mainly small, local banks, strongly rooted in the local territory, as well as financial institutions which come directly from local bodies. Finally, in the sphere of microfinance-sensitive banks it is possible to include all the banks and financial intermediaries that, for economic reasons or for the positive externalities deriving for their own image, view microfinance as an attractive opportunity. These mainly consist of banking groups, particularly large ones, or financial conglomerates which decide to enter into the microfinance sector downscaling their traditional activities - albeit to a limited extent compared to their own core business, creating specific companies or 
specialized divisions within their organizations (Molyneux - Vallelado, 2008).

\section{The nature of microfinance: microfinance vs. microcredit}

Micro-credit is defined as a credit (small amounts) provided to very poor, often unemployed people without any collateral, to help them live better ${ }^{1}$. Just small credits can help these people to repay their previous loans and start their own new business. The amount of credit is smaller and the credit cycle is shorter than standard loans of commercial institutions - typically from six to twelve months with weekly or fortnightly installments. The system of installments which is built on regular, fixed small installments starting very early after contract is signed is less encumbering for clients but is more exacting from administrative aspect.

The interest rate of microcredits seems to be very high in comparison with standard bank loans in developed part of the world. The interest earnings should cover the probability of default, inflation and mainly the administrative costs; they can be $10-25 \%$ of the sum of credits advanced by $\mathrm{MFI}^{2}$. The most of MFIs are financed externally by international organizations, NGOs or the state budgets - the measure of dependence on this revenue and self-sustainability should be the talking point in following sections.

What is microfinance? Microfinance refers to small-scale financial services - primarily credit and savings - provided to people who farm or fish or herd; who operate small enterprises or microenterprises where goods are produced, recycled, repaired, or sold; who provide services; who work for wages or commissions; who gain income from renting out small amounts of land, vehicles, draft animals, or machinery and tools; and to other individuals and groups at the local levels of developing countries, both rural and urban (Robinson, 2001).

Thus, the broader definition of microfinance includes not only microcredits but also other financial services, which can be offered to the

\footnotetext{
The poor means at least 900 million households around the world.

2 According to Muhammad Yunus, the interest rate of MFIs should be determined max. $10 \%$ above market interest rate.
} 
Dokulilová L. - Janda, K. - Zetek, P.: Sustainability of Microfinance Institutions in Financial Crisis.

poor. Interested economists soon found out that not only small credits but also other services connected with lending could improve economic lives of the poorest. In these days we can also include improvements in health care and infrastructure to the system of microfinance. The most of MFIs connect their credit services also with educational or saving programs or business trainings, retraining schemes or technical trainings. Logically the investments can be more profitable when the people have access to training, which can improve their skills. The costs of these programs obviously increase the interest rates but the gains for both the borrowers and MFIs outweigh them. For example in organizations as Pro Mujer and Freedom from Hunger, the training is a central part of the provision of credit. The courses for dressmakers are very common. After successfully passing the course, women can ask for credit on the sewing machine. The training needs to be focused not only on business or technical skills, but also on better knowledge of proper nourishment - mostly of children: the nutritious foods to feed children, the importance of breast feeding or how to treat a child with diarrhea (MkNelly, Watetip, Lassen and Dunford, 1996).

Various researchers found that the poor do not have all the expenditures in small sums, e.g. for clothing and food. From time to time they need also bigger amounts necessitated by different situations. Some can be predictable like a dowry, the education of children, home building and festivals. Very poor people spend surprisingly lot of money on various festivals (Banerjee and Duflo, 2006). Another situation can be unpredictable like emergency cases such as a sudden sickness and injury or wars, floods or other natural disasters. Finally yet importantly, the poor can face an investment opportunity such as buying land or other productive assets or setting up a new business. For these cases people should have some savings, but poor people have difficulties to save in traditional institutions or at home, thus, they try to make use of other nonofficial ways like deposit collectors, credit cooperatives or Rotating Savings and Credit Associations (ROSCA). Here is a place for another innovative component of microfinance-microsavings.

\section{Brief history of MFIs}

Over the past 10 years, microfinance has rapidly evolved and expanded from the relatively narrow field of micro enterprise credit to the more comprehensive concept of microfinance (which includes a range of 
financial services for poor people, including savings, money transfers and insurance) to the enormous challenge of building inclusive financial systems. Although the history of microfinance could be divided into several pivotal parts, the revolutionary progress was initiated in 1976 by Muhammad Yunus. This economic professor and successful founder of the Grameen Bank of Bangladesh started out by loaning 28 USD for working capital to a group of petty traders and crafts people, mostly women, in the village close to Chittagong University. With a simple system of small and frequent payments and minimal paperwork, the women paid back their loans in full and on time. In addition, micro credit program has found that women are more likely to repay their loans and in general are more reliable borrowers. But more importantly, given that microcredit's purpose is primarily social, women tend to spend their own earnings on better nutrition, housing and education for their families. This brings long-term benefits to the community, cutting into the cycle of chronic poverty and dependency. A recent World Bank study shows that wage levels are higher in the villages served by Grameen and that the health, education and self-esteem of its borrowers and their families have significantly improved (Vukson, 2003).

Many organizations from NGOs to chartered banks have followed in Grameen's steps, adapting its techniques to widely different environments. These successful advances which led to the improvement of poverty in developing countries were awarded in 2006 when Mr. Muhammad Yunus and his Grameen Bank obtained the Nobel Peace Prize "for their efforts to create economic and social development from below" (Nobel Foundation, 2006).

\section{Products and services in modern microfinance}

For a long time the offer of financial services to low-income clients meant the granting of microloans to develop microbusinesses. The beneficiaries of microcredit have typically been 'the poorest of the poor', the 'poor' and women, who have mainly benefited from small loans used to finance their cash flow. In the past decades microcredit projects have assumed wider features than their original ones. In modern microfinance the 'poorest of the poor' are no longer the only clients. All the victims of financial exclusion have now been added to the traditional target beneficiaries. In addition to developing countries, there are now industrialized countries with high levels of financial exclusion; in 
Dokulilová L. - Janda, K. - Zetek, P.: Sustainability of Microfinance Institutions in Financial Crisis.

addition to the non-profit institutions there are an ever-increasing number of traditional credit intermediaries.

The step from microcredit to microfinance requires the effort of reconsideration of the business models and the distribution methodology of financial services. It is not by chance that many authors define the current period as the 'financial services era' and underline how the recent consideration of the variety of new financial services motivates the knowledge of an increasing complexity and variety of needs of low income clients (Rutherford, 2003).

The poor, in fact, do not only need productive loans: they need further financial services in order to meet other specific needs. Examples are the demand for credit or savings in order to provide education for their children; the need for insurance services to deal with shock or emergency situations; the requirement for savings and insurance services to meet the costs of old age and funeral services. From this perspective, it is then possible to distinguish between the following needs: a) medium and long term funding needs (circulating and fixed capital), b) access to safe, fast and cheap payment systems, c) saving and liquidity needs or d) risk hedging.

Such needs can be met by using the typologies of financial services that are typically considered in the studies of financial intermediation: credit products - the most common credit products in microfinance are microcredit and microleasing. The first is offered mainly for circulating capital needs and rarely for needs in the medium to long term. The second one is for lasting needs. Some of recent experiences of micro-venturecapital can also be added to credit products.

The second most widely used group is the savings products - saving mobilization is an important tool in microfinance, both for MFIs and the clients. For MFIs the collection of the savings represents a fundamental instrument in achieving sustainability. Indeed, saving mobilization allows clients to obtain the resources to finance the growth of the loan portfolio and consequently, to become independent from subsidies or external financing. For the poor and more generally, for financially excluded people, access to deposit services allows them to manage emergencies and to meet expected expenses, such as education, marriage ceremonies, old age and death. Microbusiness incomes are often uncertain and irregular, which is something that implies difficulties in acceding to types 
of credit that require fixed regular repayments. In these cases, savings represent a fundamental instrument in the management of temporary imbalances in the microbusinesses. Furthermore, the majority of the poor receive flows of remittances from their families living in urban areas or abroad; access to deposit services is, therefore, necessary in order to keep these payments secure. In microfinance the demand for saving deposits acts with the same motivation that characterizes the formal system: savings are, in fact, the money saved today to be spent in the future for the needs of the family and for business.

Another essential financial service presents the so-called payment services - alongside savings and loan products, a limited number of MFIs have begun to offer payment services also. These are included in a category of financial services that the poor request in order to have the possibility of transferring money through secure channels. The demand for such services derives mainly from those categories of clients that have a greater managerial ability and those who need to perform transactions through alternative means to cash - often associated with deposit products - such as checks, bank transfers and credit/debit cards. Recently some MFIs have begun to offer credit cards, debit cards and smart cards. Overall the demand for payment services arises - considering the necessary exceptions - through the specific needs of banking clients: safety, availability and accessibility to payment instruments, fast and cheap settlement. On the other hand, the MFIs that offer payment services are not, so far, numerous because of the complexity of the infrastructure and the technology that the payment systems require.

Last group are the insurance products - the demand for health and loan insurance derives from the need of low-income customers to limit and cover the risks in case of death or loss of assets. Microinsurance products, drawn up to reduce uncertainty and its effects, represent a fundamental instrument in microfinance, given the vulnerability of the poor to risk. Natural disasters, health problems of the beneficiary or death of livestock, which are all events that can be dealt with by microfinance, do find in insurance cover an important management solution.

It is necessary to point out, that microinsurance is not always the best solution for reducing the vulnerability of the poor to risks and for improving the quality of the loan portfolio. Insurance is a high risk business; in developed countries this is limited to insurance companies or to financial intermediaries used to managing a single portfolio of 
numerous and similar risks. In developing countries, many MFIs operate at the limits of legality, this being due to an unfavorable legal and regulatory context and/or the inability of many MFIs to define and successfully manage microinsurance schemes. These aspects show that it is very often advisable to create partnerships with formal insurance providers, rather than offering microinsurance products directly. These partnerships present various advantages for formal insurers as well as for MFIs. The insurers can gain access to new markets, MFIs can benefit from the expertise of formal institutions in defining client responsive products, without having to spend time and resources in the design phase of the product. On the other hand, offering insurance products directly involves incurring greater risks, especially if the insurance side of the business is not separated from the savings and the credit side. Furthermore, directly offering insurance products requires different skills from those required for credit or saving supply. Finally, the MFIs can incur more moral hazard problems (Torre La - Vento, 2006).

\section{Problems affecting MFIs}

Although there have been various successful stories about microfinance institutions helping the poor, they face many problems. The problems can be solved on many occasions but sometimes cannot be avoided. We discuss the problems MFIs face under the following broad categories.

1. Ethical Reasons: Microfinance institutions can be often viewed as a profit making organization. The desire to make MFIs an industry, commercialize micro-lending or enable them to be a profit making institutions should not distract them from one important aspect for which they are formed in the first place: social service by enabling poor to work on profit making projects or small businesses. Many times, the lack of this aspect can lead the microfinance institutions to behave similarly to the local moneylenders. Furthermore, the important point of corruption cannot be neglected. Another reason of failure has been the lack of motivation. MFIs thrive on better economical conditions and an economic down turn can incur heavy 
loss on them. In such adverse situations, MFIs generally lose man power too ${ }^{3}$.

2. Managerial Reasons: One of the major problems which the MFIs can resolve is managerial problems. They tend to be fairly straightforward and the solutions to them are also pretty straightforward. Managerial problems are a major factor and they have more effects than any other problems discussed. These problems include mainly: lack of management training, poor record keeping and obviously lack of management capacity.

3. Legal Reasons: Microfinance institutions can be viewed as a social organization helping the poor but also as a profit organization. In many countries, profit organizations are registered under different set of acts and non-profit organizations come under different legislations. On the first view, it could seem unsubstantial, but these legalities sometimes create complications ${ }^{4}$.

4. "Unfortunate" Reasons: Sometimes microfinance institutions have to face problems which cannot be resolved. These problems arise in cases when something "unfortunate" happens to a person or a community (e.g. a flood or famine can kill the hopes of farmers to pay their loans).

5. Other Reasons: There are various other factors for the failure of MFI. Firstly: a) lack of vision is a factor which pushes new MFIs into extinctions. Formation of an MFI requires considerable research and should have a clear cut vision of why they are operating and the clients they will be serving. Sadly, due to lack of research MFIs set up by NGOs fail to scale up. b) MFIs need trained staff in order to

3 In Tanzania, during economic down turn the MFIs performed poorly because of lack of motivation, resulting in below par loan repayment.

4 For example, TBF had to face some problems such as how to lend loans as a charitable organization in India. In India, TBF cannot register as a bank given the enormous barriers for becoming one. Instead, TBF resorted to register itself as a charitable foundation and trust, which enabled it to receive funds internationally and domestically for development purposes. But as a charitable foundation, TBF was not allowed to indulge in money lending and hence all loans distributed by them were entered as "aid". The repayments were entered as "donations" with $8 \%$ service fee. In an idealized situation this is good but TBF still has to face chronic defaulters who don't repay loans. The usual tactics in this case entail a combination of personal persuasion and religious obligations. 
Dokulilová L. - Janda, K. - Zetek, P.: Sustainability of Microfinance Institutions in Financial Crisis.

operate. In several cases, drop out of trained staff is very high which reduces the reach of an MFI. Furthermore, the "dropping out" rate is more than the "coming in" rate. c) MFIs serve society but they are also a profit-making institution. In many cases, MFIs achieve a lot of success in their programs in initial period, but they fail to maintain the same record in the long run because of lack of proper commercial orientation, thus making them unsustainable.

\section{The historical financial crises and their impact on MFIs}

Before the discussion of the microfinance aspects of the current global financial crisis, we will provide a few comments on the previous recent crises. We will obviously concentrate on the lesson which the microfinance could draw from those crises.

We will start with the Asian financial crisis in the second half of 1990 's. The causes of this crisis are mix of different reasons but common factors included overvalued exchange rates, structural weaknesses in the financial sector and excessive short-term borrowing (role of IMF) leading to asset price inflation, speculation and increases in nonperforming loans. These events led to recession in number of East Asian countries, slower growth, sharp increase of unemployment, increased inflation and higher interest rates. The most badly affected countries were Thailand and Indonesia. On the contrary, the Philippines survived initial shock well and little impact can be observed also in India and other South Asian countries.

This economic and financial crisis could offer number of potential implications for microfinance. The economic recession resulted in fewer job opportunities in the formal sector, forcing more people into informal sector of economy. In combination with higher poverty, this increased number of potential microfinance clients - borrowers especially. At the same time, the profitability of microenterprises fell, which was caused by increased competition among microentrepreneurs and reduced demand for their output. Resources for government development programs, often supporting MFIs, decreased. The weaknesses in financial institutions and overall financial system were made more visible in conditions of the crisis. 
All these effects of crisis had direct and indirect implications for microfinance. The preliminary results of survey of BWTP ${ }^{5}$ (April 1998) and survey of McGuire and Conroy (1998) were that the crisis affected more Indonesia than other countries, although other countries as the Philippines, Malaysia and Thailand were influenced. The crisis had greater impact on institutions serving small business clients than on specialist MFIs serving the poor. And logical conclusion is that MFIs that were more linked into the formal financial system suffered more.

As another significant financial crisis could be regarded the financial crisis in Latin America in years 1998 and 1999. The mainly discussed affected countries were Argentina, Brazil and Mexico, but also other countries suffered heavily without such publicity - including Bolivia, Colombia, Ecuador and Peru. There were other factors which contributed to deterioration of this crisis in particular countries - civil war in Colombia, the El Niño-Southern Oscillation phenomenon in Peru and Ecuador and the crackdown on coca production in Bolivia. The economic slowdown heavily influenced the financial statements of commercial banks - growth of loan portfolio stagnated, profitability fell and problems with loan repayments began to rise. The banking regulators were trying to prevent growing number of banks' falls. The MFIs were not immune to the economic situation in Asia as well as in Latin America, but after years, we could say that well-established MFIs performed as well or even better than their counterparts in the commercial part of the banking sector. Some MFIs showed that their business strategy could be also a powerful tool for surviving and growing in hard times.

For example, in terms of growth the leading MFIs of Bolivia, Colombia and Peru have outperformed countries' commercial banks every year since 1997. After hard times in 1998 and 1999, the portfolio growth of MFIs reached substantially high level in $2000-47.9 \%$ in Peru and $26.8 \%$ in Colombia. At the same time, although growth of commercial banks' portfolios also improved slightly, they still reported almost no growth rates. In case of Bolivian MFIs, they still outperformed country's commercial banks every year from 1997 but the pace had slowed. The worst time of Bolivian MFIs was in 1999, when Borrowers' Revolt took

5 The Banking with the Poor (BWTP) Network initiated survey of the impact of the crisis on microfinance. Survey covered nine Southeast Asian (Indonesia, Malaysia, the Philippines and Thailand) and South Asian (Bangladesh, India, Nepal, Pakistan and Sri Lanka) countries (McGuire, 1998). 
Dokulilová L. - Janda, K. - Zetek, P.: Sustainability of Microfinance Institutions in Financial Crisis.

off. The commercial banks of Bolivia and Peru managed to keep their returns on breakeven level, but Colombian banks experienced substantial fall of profits.

On the other hand, MFIs managed to maintain not only high growth rate of portfolio but also its quality during the crisis. For example in Colombia through the period 1997 - 2000, the loan delinquency rates of MFIs were kept near to level of $3 \%$ but rose to double digits for commercial banks. The MFIs used many strategies to prevent bad impacts of crisis but the three general types can be identified - survival (case of FIE), consolidation and growth. These tactics had evidently a common goal to maintain healthy portfolio, liquidity, solvency and low recovery and operating costs. The MFIs with sufficient capacity and preparation could begin to serve new segment of clients or to offer new services. But all these strategies have depended on preserved loyalty of clients and adaptability of both clients as well as MFIs. The ability of adaptation of low-income individuals and enterprises was the key advantage for MFIs in comparison to large commercial institutions serving wealthier clients. The MFIs, as Argentinean FIE, were inspired by adaptability of their clients and began to adjust their business activities to survive the period of crisis - extension of open hours, working also on Sundays, visiting clients in their shops and homes, extension of repayment period or rescheduling of delinquent loans.

The next important factor which helped MFIs to survive was the international assistance during crisis. The study of Westley and Shaffer (1999) which stated that microenterprises in Brazil, Mexico, Belize and the Dominican Republic generated $20 \%$ of their GDP, influenced big financial institutions as the IDB to support microfinance sector. In period from 1990 to 1999, the IDB financed Latin American microfinance projects by the amount of more than US\$ 690 million. Such international financial injections were important for example for Banco Solidario, Ecuador. Because of its well-organized business plan, they received US\$ 30 million from group of international investors when Ecuadorian government was not able to obtain financial aid.

\section{The Current Financial Crisis \& MFIs}

The pending crisis already began in mid-2000s when the US economy shifted to an imbalanced macroeconomic position on both internal and 
external levels (Teplý, Černohorský and Černohorská, 2009). In 2007 problems of the US subprime market materialized and resulted in the US market instability, unleashing a global financial contagion that spread around the world, roiling markets and causing world economic upheaval. Relaxed lending standards and lack of transparency of the US subprime mortgage market has taught risk management lessons that will be crucial for future financial markets development. For instance, NINJA ${ }^{6}$ loans were provided intentionally to applicants with a low creditworthiness while requiring only little information about the applicant (Chalupka and Teplý, 2008).

As a result, the present global credit crisis does not seem to be an ideal situation for providing unsecured loans to very poor people without relevant credit history. However in comparison with other financial institutions, the MFIs have survived past financial crises relatively not affected. As we have seen, during the Asian crisis and crisis in Latin America the institutions serving poor people generally performed better than commercial banks.

The size of impact depends on several factors, such as structure of institution's liabilities, institution's financial state and economic health of clients. So far, there is little evidence showing that microclients have been affected by the crisis. Moreover, it is not easy to identify which effects are directly related to the crisis and which are connected to preexisting situations or conditions.

The most of MFIs successfully survived past financial crises, but history does not have to be the guide for predicting the outcomes of all future crises. Microfinance is much more connected to financial market during the current global financial crisis than it was during the previous crises; many MFIs are already transformed into regulated deposit-taking banks with access to commercial funding sources. By the early 2000s, MFIs have appeared on international capital market - first microfinance IPO of Bank Rakyat Indonesia and the emergence of microfinance collateralized debt obligations (CDOs) as well as IPO of Mexican Banco Compartamos. The IPO involved secondary offering of $30 \%$ of bank's stock and raised substantially US\$ 40 million, yielding to investors the international rate of return of over $100 \%$ compounded over 8 years. The bank's issue was 13 times oversubscribed (Watson, 2009).

6 No Income, No Job, No Assets. 
Dokulilová L. - Janda, K. - Zetek, P.: Sustainability of Microfinance Institutions in Financial Crisis.

By 2007, the worldwide MFIs had received (estimated) US\$ 5 billion of foreign investment from developed countries. As result, present microfinance system is connected to global markets by unprecedented degree. And these markets withstand to high degree of turmoil combining the worst effects of crises in 1990s. The global trade of year 2009 is projected to contract for the first time from 1982. Both GDP growth of developing countries and private capital flows to developing countries are projected to fall to roughly half of their 2007 levels. There are reductions emerging in foreign investment and remittance flows, increases in country risk premiums and local credit spreads (Watson, 2009).

The full effect of the global crisis and its triple shocks - economic contraction, currency depreciation and scarcity of credit, will fully show its power in emerging countries in the second half of year 2009. MFIs' PAR +30 ratios already increased in the first quarter of 2009, but still remains below 5 percent for the most leading MFIs (CGAP). This year will be a key year to test the resilience of microfinance to macroeconomic turmoil.

Recent data so far show that global financial crisis will stress MFIs and their clients, but the sector is quite robust and may emerge even stronger than before. The crisis has pointed out MFIs to the important role of local sources of funding. When international funding taps dry up, local deposits become even more critical to fuel MFIs' lending.

Generally, the growth of the microfinance sector is (and will be) halted and is predicted not to reach more than $20 \%$ per year in case of Mexico. This number is visibly lower than in the past, when the growth attained records of $40-50 \%$ per year. Another effect will be the consolidation of MFIs and thus the number of microfinancing entities will slightly decline. However, the sector will be less affected than other major economic sectors as the crisis will affect its growth and quality of assets, but will not cause any major disruption, due to relative isolation of the microfinance markets from the beat of the global economics. The crisis will thus help the strongest ones and hurt the young and weak ones.

Furthermore it is necessary to keep in mind that borrowers in foreign currency are exposed to the risk in the form of exchange rate fluctuations. Local banks funding MFIs are limited by global conditions. The MFIs could find difficult to refinance already existing debts. According to IFC, most MFIs have loans with one or two years' maturity and there is 
potential refinancing gap of US\$ 1.8 billion over the next 12-15 months. These problems with financing could encourage some MFIs to become legally regulated institutions able to collect deposits instead of constant chasing for funds. From this point of view, we can say that MFIs mostly affected by global liquidity contraction could be non-deposit taking MFIS funded primarily by foreign debt. The money from domestic and international banks and funds are limited, slower and more expensive ${ }^{7}$. The increasing interest rates, FX losses and more expensive funds lead to increase in operating costs, which are not always transferable on their clients. Thus, deposit-taking MFIs should survive the crisis better. Many of them are well isolated from refinancing risk and have a little (if any) need for external funding.

Many deposit-taking MFIs collect not only deposits from the poor but also from the non-poor customers. Here should be problem, because the non-poor depositors could be more sensitive to the economic downturn. The loss of confidence and run on deposits in USA and Europe can also lead to the same reaction in developing countries. The high withdrawals are and will be caused by high prices of food and energies and lower remittances. Another reason could be that at least some microloans finance consumption, not investment, and thus debtors will need to withdraw their savings or use new loan for paying them off. This could work as long as new credit will be available. For example many Mexican MFIs repay in advance their USD liabilities, in order to prevent FX related problems and in many cases register reduction of the demand for microcredit. According to data of Prodesarollo, 60\% of Mexican MFIs are threatened due to reduction of funding.

Many microbusinesses serve local needs by basic products, which could be unaffected or even supported by crisis. In time of crisis, people prefer cheaper or less quality products, which microbusinesses usually offer. Microenterprises, as in previous crises, are very adaptable. Microentrepreneurs could adjust to deteriorated conditions by involving more family members in business or by adjusting the portfolio of products and/or their prices. Businesses serving subsistence goods as food and clothes could even earn on crisis because the demand for these goods remain steady in any times. MFIs highly serving SMEs, which have tendency to be more influenced by economic slowdown, or focused on

7 According to CGAP, the rates in Latin America and South and Central Asia grew from $1 \%$ to $4 \%$. 
Dokulilová L. - Janda, K. - Zetek, P.: Sustainability of Microfinance Institutions in Financial Crisis.

consumer lending will suffer the most. Also, the decreasing remittances from abroad will have bad effect on microclients, which used microloans as consumption loans, and remittances are used for repayments.

The financial problems of MFIs could provoke the loss of confidence that MFIs could be able to provide other loans. In this situation, the debtors could lose incentives to repay their already existing debts. The microfinance system is established, among others, on the principles of mutual responsibility and the confidence in future funding in case of no repayment problems. Therefore, why should microcreditors repay their loans when no else will be available? This could deteriorate the MFIs' loans portfolio quality and MFIs should focus more on monitoring their clients and efforts on clients' confidence.

Naturally, smaller and younger MFIs are more affected than older and bigger players. According to CGAP survey, 64\% of small MFIs have reported funding problems in past six months in comparison to only $35 \%$ of large MFIs. Small and medium MFIs seem to be more fighting with liquidity issues $-74 \%$ of managers of MFIs from the survey have expected that their liquidity situation will worsen in the next six months. Regionally, the most pressing needs for capital appear in Sub-Saharan Africa and South Asia - 68\% and 57\% of MFIs, respectively, report the liquidity problems ${ }^{8}$.

The impact of the crisis on microfinance sector will also differ by geographical location of MFIs. The location of MFIs is important factor because of economic, regulatory and country-specific conditions influencing development of MFIs. The governments' measures could help but also hurt MFIs. The risks of government interventions include interest-rate ceilings, mass loan forgiveness, encouragement of delinquent borrower associations and development of credit programs in government agencies that lack financial expertise and so on. Some of these tactics could be already observed in several countries of Latin America (Gonzalez-Vega, 2008, p. 8). On the other hand, the government interventions could encourage the transformation of MFIs in regulated subjects which are able to mobilize deposits or adaptation of cautious, better, lending policies.

8 According to surveyed MFI's assets, they were distributed in three groups: Tier 1 assets above US\$50 million, Tier 2 - assets in range of US\$3 million - US\$ 50 million and Tier 3 - assets below US\$ 3 million. 
According to separation by regions, we can analyze impact of crisis on MFIs in particular segments - East Asia and the Pacific, Latin America and the Caribbean, Middle East and North Africa, Eastern Europe and Central Asia, South Asia and Sub-Saharan Africa. In March 2009, CGAP surveyed over 400 MFIs from all regions to identify present impacts of crisis ${ }^{9}$.

\section{East Asia and the Pacific - EAP}

The region was hit relatively hard by the food crisis, although many economies in this region are specialized on agriculture. In 2005-2007, the food prices increased by $12.4 \%$ in rural areas and $13.8 \%$ in urban areas, the number of poor people increased by $4.9 \%$ in rural areas and by $6.3 \%$ in urban ones (World Bank, 2009a). The microclients are thus spending higher share of their income on food and basic goods. Savings are decreasing because they are replaced by basic consumption. Female microlenders are probably hit harder than in other regions, they should work more and harder, eat less to be able to feed their families. Logically, people working in export-oriented businesses, construction and tourism are significantly affected. The growth of economies is slowing down $8 \%$ in 2008 and $5.3 \%$ in 2009, but will be probably higher than in the rest of the world, mainly driven by China (World Bank, 2009b). According to the list of the fastest growing microfinance markets published in MBB no. 17, autumn 2008, the Philippines, China, Indonesia and Cambodia are among top 20 for $2006-2007^{10}$.

According to CGAP, $77 \%$ of DFI loans to MFIs are denominated in hard currency. The investment flows still does not stop - four international investors provided capital injection of US\$ 5 million to Bank Sri Partha, Indonesia in April 2009. Korea postponed the implementation of the Basel II from January 2009 to 2010 because of low remaining capital and thus ease liquidity. Moreover, the Korean government promised to provide almost US\$ 73 million in direct loans

9 CGAP asked over 400 MFI managers in different regions. LAC - 114 MFIs, MENA - 29 MFIs, SSA - 115 MFIs, SA - 59 MFIs, EAP - 26 MFIs, ECA - 44 MFIs. Around 76 percent of respondents were institutions of Tier 2 or 3, assets below US\$ 50 million. Credit unions and cooperatives represented 14.5 percent of sample. The survey was publicized in May 2009.

10 The MBB publicized list of countries which have aggregate growth in borrowers above the 20 percent global median. 
Dokulilová L. - Janda, K. - Zetek, P.: Sustainability of Microfinance Institutions in Financial Crisis.

and guarantees to micro and small businesses in financing troubles (Watson, 2009).

Although, most MFIs - 69\% - has reported deterioration of loan portfolio quality, in EAP region is the ratio lower - 58\% - with expectation of decrease in next 6-12 months. The portfolio has declined or stagnated in two thirds of cases, but predictions for next months are positive. Half of respondents recorded limitations because of liquidity contraction.

\section{Eastern Europe and Central Asia - ECA}

The ECA region seems to be most affected by the crisis. The crisis caught many countries of region in very vulnerable position caused by relatively high current account deficits, elevated external debt levels, very rapid credit growth and consumption boom financed by foreign borrowing. In addition, the highly leveraged microfinance market is really exposed to troubles of less liquidity and refinancing risk. According to CGAP, $84 \%$ of DFI loans to MFIs are denominated in hard currency. Fortunately, multilateral funders - EBRD, EIB and WB - promised to provide up to US\$ 24.5 billion as a support for banking sector for funding businesses in the region. Good news is that Tajikistan, Azerbaijan, Bosnia, Kyrgyzstan, Kosovo and Armenia belong among 20 fastest growing microfinance markets worldwide. On the other side, the real incomes steeply declined due to currencies depreciation in the second half of $2008-30 \%$ for Hungary, $40 \%$ for Poland, 25\% for Turkey and $70 \%$ for Ukraine. The number of poor and vulnerable people is expected to rise by about 5 million people for every 1 percent decline in GDP.

According to CGAP survey, the microclients of this region appear to be the most affected where the urban clients seem to be more affected than rural ones. The unemployment is increasing, remittances decreasing, profits of microentrepreneurs going down - all these factors lead to repayment difficulties higher than in other regions. $87 \%$ of surveyed MFIs answered that their PAR +30 has increased in last six month. And more than half of respondents reported that their gross loan portfolio went down in the last six months. 


\section{Latin America and the Caribbean - LAC}

According to IMF, eight of twenty developing countries whose economies have reacted most sharply to economic deterioration measured by exchange rate depreciation, increase in spreads and equity market declines - are situated in LAC region. Some countries of this region are among the countries with the highest developed microfinance markets and have been the cradle of commercial microfinance. The exposure to currency volatility is high $-73 \%$ of DFI loans to MFIs are denominated in hard currency. These could be the two reasons why the crisis has hit this region hard. On contrary, Mexico and Bolivia successfully have resisted the deteriorated economic conditions. Moreover, Mexico and Haiti are among the 20 fastest growing microfinance markets worldwide. In the first quarter of 2009, Mexican Banco Compartamos reported net profit of US\$ 21.9 million and 44,000 of new clients in its portfolio.

Microclients in this region are the most affected by crisis, by high and volatile food prices, after ECA region. The repayment capacity is lower, the business activity and volume of remittances from abroad are decreasing - according to WB's outlook the annual percent change will be in range of $(-4.4,-7.7)$ in 2009, increasing again in 2010. Two thirds of respondents answered that clients in urban areas are the most affected. Together with women, they are facing more repayment difficulties - three quarters of respondents indicated that their clients have problems with repayment. $71 \%$ of respondents reported increase in PAR +30 in the last six months.

\section{Middle East and North Africa - MENA}

So far, MENA region has been less exposed to the impact of global crisis. Many economies in this region are growing, rate of unemployment is stable in most of countries and local banks are still not facing liquidity troubles. MFIs are also less affected, partly because of the fact that investment in microfinance sector is largely driven by DFIs and there is only low exposure to currency volatility $-16 \%$ of DFI loans to MFIs are denominated in hard currency. The growth of region is expected to decline from $6 \%$ in 2008 to $2.5 \%$ in 2009. 
Dokulilová L. - Janda, K. - Zetek, P.: Sustainability of Microfinance Institutions in Financial Crisis.

The microclients are significantly less affected by crisis than in the rest of the world. Lower segment of clients have not experienced any drastic economic slowdown yet, only less willingness to expansion and credits from bigger borrowers. In the period of 2005-2007, food prices increased by $25.9 \%$ in rural areas and by $12.5 \%$ in urban areas. Securing food expenditures remains priority but it is less problematic than in other regions, namely in comparison to the rest of the African continent. Only Morocco seems to be seriously affected, but not only from reasons directly related to the crisis.

Microfinance sector seems to be quite healthy, due to the fact that many MFIs in the region operate in highly regulated financial markets. MFIs in this region have the highest equity to asset ratios of all regions and Morocco and Egypt belong among the 20 fastest growing microfinance markets worldwide. $67 \%$ of respondents reported that they had not to face any liquidity constraints in past six months. Gross loan portfolio has increased in $46 \%$ surveyed MFIs and 62\% MFIs reported increasing of PAR +30 .

\section{South Asia - SA}

In 2008, GDP growth rate in SA region decreased substantially to $6.3 \%$ from $8.4 \%$ in 2007 . Even before the crisis, the region was affected by rising inflationary pressures and tight credit conditions. The banking sector has been rather isolated from effects of crisis as its exposure to toxic assets has been very limited, the exposure to currency volatility is low - only $18 \%$ of DFI loans to MFIs are denominated in hard currency.

Disturbing fact is that large proportion of the region's population is poor and thus highly vulnerable to changes in credit availability. The higher prices of food force microclients to spend more of their income on substantial food, their savings capacity is decreasing. According to CGAP, $10 \%$ increase in food prices would lead to an estimated increase of $4.4 \%$ in poverty headcount in urban areas and $1.7 \%$ in rural areas.

Concerning microfinance, India, Pakistan and Afghanistan are among the 20 fastest growing microfinance markets worldwide. Moreover, Indian initiatives to increase liquidity and lower foreign exchange risk have made difficult for the crisis to affect the microfinance sector. According to Watson (2009), the increased foreign lending restrictions applied by the Central Bank to non-bank financial companies, many of 
which are MFIs, let the rupee depreciate, which slowed down the outflow of capital and has been providing extra funding for financial sector. The overall impact of crisis on the region has been limited until now, also because of proactive measurements of governments like these in India.

\section{Sub-Saharan Africa - SSA}

Although SSA region is the developing region least integrated into global economy, growth is supposed to fall from 5.5\% in 2008 to $1.7 \%$ in 2009. Many of the poor were already hit by recent increases in food prices and sharp declines in remittances' to the region from abroad. Even though some countries as Senegal have experienced rise in remittances.

Due to high food price volatility - i.e. food staple price inflation is $40 \%$ in Kenya and 27\% in Zambia; the share of income spent on food is also increasing. According to Global Economic Prospects 2009, the 10\% increase in food prices would lead to estimated increase of $2.8 \%$ in poverty headcount in urban areas. Because of strong saving base, the microfinance sector in SSA is less dependent on international capital and donors' money. The levels of deposits are high especially in countries of Western Africa. There is only moderate exposure to currency volatility only $31 \%$ of DFI loans to MFIs are denominated in hard currency. Moreover, only small part of MFI debt is priced at commercial rates. The shortage of demand for microentrepreneurs' products and higher prices of basic inputs have severe effect on microclients. The clients are facing decreasing savings because of more money spent on food and thus increasing difficulties with repayments.

Only Togo and Kenya are among the 20 fastest growing microfinance markets worldwide. According to Watson (2009), the key problem of MFIs in Kenya is the repayment rate. One of MFIs, Jamii Bora, has seen increase in non-performing loans due to lower sales of clients' businesses. In May 2008, the Kenyan government implemented Kenyan Microfinance Act which enabled to regulate MFIs to accept clients' deposits. It could be expected that these deposit taking MFIs survive better the crisis.

\section{Conclusions}

Our discussion shows that MFIs are very useful instrument for elimination of problems of poverty and stimulation of small businesses in 
Dokulilová L. - Janda, K. - Zetek, P.: Sustainability of Microfinance Institutions in Financial Crisis.

developing countries. Microfinance is a dynamic field of business and there is clearly no best way to deliver products and services to the lowincome people. From this point of view, the microfinance clients (or participants) are not only provided with microcredits and microsavings but they may receive also microinsurances or micropayments, which are not so much utilized otherwise due to relatively enormous high costs. Nevertheless, MFIs are currently forced to innovate these services according to client's wishes.

On the other hand, we could identify a lot of barriers, which obstruct easier and faster development of these institutions for example: ethnical problems, managerial resources, legal recourses, unfortunate recourses and others. The size of that negative impact for MFIs depends on several important factors like geographical, economical, political and social conditions.

While the performance of microfinance institutions is in general quite well documented and researched, there are still open questions about microfinance ability to survive during financial crises. Generally, the experience of MFI with past crisis was positive. On one hand, MFI were able to survive major macroeconomic disturbances because of its close links with the micro-foundations of the economy. On the other hand, the microfinance institutions in the times of crises benefited from the international help which concentrated on the basic survival of the less wealthy part of the population. Therefore this international help was either channeled through microfinance institutions or it help them function due to secondary transmission.

The current global financial crisis is different because of its global nature - the global transfers and humanitarian help is no longer available in such scale as in the regional crises. This restricts the sources for microfinance. From the regional point of view, the impact of the global crisis on microfinance is the most adverse in the Eastern Europe and Central Asia region, while it is relatively mild in other regions, where the microfinance was traditionally utilized.

However, the main test of resilience of microfinance system to current global economic events will come during the years at the end of global financial crisis and after this crisis. The MFIs are much more connected to international financial market than before. The impact of the crisis has already appeared in tightening of capital sources and lower demand for 
product of microentrepreneurs. Nevertheless, microfinance sector is known for its adaptability in past crises and it performed relatively well in the current global financial crisis as well.

\section{References}

[1] Banerjee, A. V. - Duflo, E. (2006): Economic Lives of the Poor. Journal of Economic Perspectives, 2006, vol. 21, no. 1, pp. 141-167.

[2] Čechura, L. (2009): The Impact of Credit Rationing on Farmer's Economic Equilibrium, Agricultural Economics (Czech), 2009, vol. 55, no. 11, pp. 541-549.

[3] Čechura, L. (2008): Theoretical-Empirical Analysis of the Role of the SGAFF in Financing of Farmers' Activities. Agricultural Economics (Czech), 2008, vol. 54, no. 10, pp. 476-488.

[4] Čechura, L. (2006): The Role of Credit Rationing in Czech Agriculture - The Case of Large Agricultural Enterprises. Agricultural Economics (Czech), 2006, vol. 52, no. 10, pp. 477-488.

[5] Gonzalez-Vega, C. (2008): Summary of the Virtual Conference on the Financial Crisis. [on-line], Washington, D.C., Consultative Group to Assist the Poor, c2008, [cit. 24 ${ }^{\text {th }}$ November, 2009], <http://www.cgap.org/gm/document-1.9.7439/CGAP\%20Virtual\%2 0Conference\%202008\%20Summary.pdf>

[6] Chalupka, R. - Teplý, P. (2008): Operational Risk Management and Implications for Bank's Economic Capital - A Case Study. [on-line], Charles University in Prague, Institute of Economic Studies Working paper 17/2008, c2008, [cit. 24 ${ }^{\text {th }}$ November, 2009], <http://ies.fsv.cuni.cz/default/file/download/id/8933>

[7] McGuire, P. B. (1998): The Asian Financial Crisis: Some Implications for Microfinance. The MicroBanking Bulletin, 1998, vol. 2, no. 2, pp. 9-12.

[8] McGuire P. B. - Conroy J. D. (1998): Effects on Microfinance of the 1997-1998 Asian Financial Crisis; Brisbane, The Foundation for Development Cooperation, 1998.

[9] MkNelly, B. - Watetip, C. - Lassen, C. A. - Dunford, C. (1996): Preliminary Evidence That Integrated Financial and Educational Services Can Be Effective Against Hunger and Malnutrition. Davis, Freedom from Hunger Research Paper no. 2, 1996. 
Dokulilová L. - Janda, K. - Zetek, P.: Sustainability of Microfinance Institutions in Financial Crisis.

[10] Molyneux, P. - Vallelado, E. (2008): Frontiers of Banks in a Global Economy. Basingstoke, Palgrave Macmillan, 2008.

[11] Nobel Foundation (2006): The Nobel Peace Prize for 2006. [on-line], Stockholm, Nobel Foundation, c2009, [cit. 10 ${ }^{\text {th }}$ November, 2009], <http://nobelprize.org/nobel_prizes/peace/laureates/2006/press.html>.

[12] Robinson, M. S. (2001): The Microfinance Revolution, Sustainable Finance for the Poor, Lessons from Indonesia, The Emerging Industry. Washington, D.C., World Bank, 2001.

[13] Rutherford, S. (2003): Raising the Curtain on the Microfinancial Credit Era. In Harper, M. (ed.): Microfinance. Evolution, Achievements and Challenges. Rugby, ITDG, 2003.

[14] Teplý, P. - Černohorský, J. - Černohorská, L.: (2009): Strategic Implications of The 2008 Financial Crisis. In Kuofie, M. H. (ed): World Summit on Global Economic Crisis. Beverly Hills, Global Strategic Management, 2009.

[15] Torre La, M. - Vento, G. A. (2006): Microfinance. Basingstoke, Palgrave Macmillan, 2006, p. 20-38.

[16] Vukson, W. B. Z. (2003): Emerging Markets \& Special Surveys. Toronto, G7 Books, 2003.

[17] Watson, Y. (2009): From Crisis to Catharsis: How Microfinance Can Make it Through the Global Recession. [on-line], Mumbai D.C., Microfinance Insights, $1^{\text {st }}$ March, 2009, [cit. $10^{\text {th }}$ November, 2009], <https://www.microfinanceinsights.com/articles_new.asp?id=411>.

[18] Westley, G. D. - Shaffer, S. (1999): Credit Union Policies and Performance in Latin America; Journal of Banking and Finance, 2007, vol. 23, no. 9, pp. 1303-1329.

[19] World Bank (2009a): Global Economic Prospects, Commodities at the Crossroad. [on-line], Washington, D.C., World Bank, c2009, [cit. $10^{\text {th }}$ November, 2009],

<http://siteresources.worldbank.org/INTGEP2009/Resources/10363_ WebPDF-w47.pdf>.

[20] World Bank (2009b): Updates Poverty Estimates for the Developing World. [on-line], Washington, D.C., World Bank, c2009, [cit. $10^{\text {th }}$ November, 2009], <http://siteresources.worldbank.org/INTEAPHAL FYEARLYUPDATE/Resources/550192-1238574864269/5976918-1 239010682147/update_april09_fullreport.pdf\#39>. 


\title{
Sustainability of Microfinance Institutions in Financial Crisis
}

\author{
Lenka DOKULILOVÁ - Karel JANDA-Pavel ZETEK
}

\begin{abstract}
The aim of this paper is to clarify the problems of microfinance and the sustainability of microfinance institutions (MFI) in financial crisis. We find, that MFIs are often considered as one of the most effective and flexible strategies in the fight against global poverty. Due to several often unsolvable problems obstructing the easier and faster development of these institutions such as: ethnical problems, managerial resources, legal recourses, unfortunate recourses and other, the operations of MFIs are often not sufficiently efficient. The microfinance sector is in general known for its adaptability and quite healthy survival of past financial crises. However, current global financial crisis is testing the resilience of MFIs hardly. The MFIs are much more connected to international financial markets now than it was the case during previous crises. Therefore we expect that they will not survive the crisis without bearing some loses. But the expected losses are relatively smaller when compared to other financial institutions.
\end{abstract}

Key words: Financial crisis; Microfinance; Microcredit; MFIs.

JEL classification: G01, G21. 